\title{
Flux and composition of settling particles across the continental margin of the Gulf of Lion: the role of dense shelf water cascading
}

\author{
C. Pasqual ${ }^{1}$, A. Sanchez-Vidal ${ }^{1,2}$, D. Zúñiga ${ }^{1,4}$, A. Calafat ${ }^{1}$, M. Canals ${ }^{1}$, X. Durrieu de Madron ${ }^{2}$, P. Puig ${ }^{3}$, \\ S. Heussner ${ }^{2}$, A. Palanques ${ }^{3}$, and N. Delsaut ${ }^{2}$ \\ ${ }^{1}$ GRC Geociències Marines, Universitat de Barcelona, 08028 Barcelona, Spain \\ ${ }^{2}$ CEFREM, UMR-CNRS 5110, Université de Perpignan, Via Domitia, 52 av. P. Alduy, 66860 Perpignan, France \\ ${ }^{3}$ Institut de Ciències del Mar, CSIC, Pg. Marítim de la Barceloneta 37-49, 08003 Barcelona, Spain \\ ${ }^{4}$ Instituto de Investigacións Mariñas, CSIC, Eduardo Cabello 6, 36208 Vigo, Spain
}

Received: 16 July 2009 - Published in Biogeosciences Discuss.: 31 July 2009

Revised: 14 December 2009 - Accepted: 29 December 2009 - Published: 15 January 2010

\begin{abstract}
Settling particles were collected using sediment traps deployed along three transects in the Lacaze-Duthiers and Cap de Creus canyons and the adjacent southern open slope from October 2005 to October 2006. The settling material was analyzed to obtain total mass fluxes and main constituent contents (organic matter, opal, calcium carbonate, and siliciclastics). Cascades of dense shelf water from the continental shelf edge to the lower continental slope occurred from January to March 2006. They were traced through strong negative near-bottom temperature anomalies and increased current speeds, and generated two intense pulses of mass fluxes in January and March 2006. This oceanographic phenomenon appeared as the major physical forcing of settling particles at almost all stations, and caused both high seasonal variability in mass fluxes and important qualitative changes in settling material. Fluxes during the dense shelf water cascading (DSWC) event ranged from $90.1 \mathrm{~g} \mathrm{~m}^{-2} \mathrm{~d}^{-1}$ at the middle Cap de Creus canyon $(1000 \mathrm{~m})$ to $3.2 \mathrm{~g} \mathrm{~m}^{-2} \mathrm{~d}^{-1}$ at the canyon mouth $(1900 \mathrm{~m})$. Fractions of organic matter, opal and calcium carbonate components increased seaward, thus diminishing the siliciclastic fraction. Temporal variability of the major components was larger in the canyon mouth and open slope sites, due to the mixed impact of dense shelf water cascading processes and the pelagic biological production. Results indicate that the cascading event remobilized and homogenized large amounts of material down canyon and southwardly along the continental slope contributing to a better understanding of the off-shelf particle transport and the internal dynamics of DSWC events.
\end{abstract}

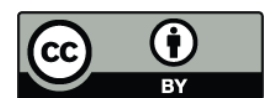

Correspondence to: A. Calafat (antonicalafat@ub.edu)

\section{Introduction}

Continental shelves are bypass zones of lithogenic and biogenic material from their source in the continent to their sink in the deep sea floor. In addition, high biological production takes place in shelf regions due to nutrients inputs from land and coastal upwelling. In those environments, settling material is subjected to biological, physical and chemical processes among which the remobilization basinwards supposes the principal way of shelf erosion. Actually, experiments carried out in the Western Mediterranean Sea show differences of three orders of magnitude when comparing settling particles in the slope with the open basin, underlining the importance of continental shelves as a source of material for the adjoining slope environment (Heussner et al., 2006; Martín et al., 2006; Zúñiga et al., 2009). Suspended particles on the continental shelf are mainly advected to the slope through intermediate or bottom nepheloid layers (Durrieu de Madron and Panouse, 1996), resulting in larger particulate fluxes closer to the slope bottom (Monaco et al., 1990; Heussner et al., 1999, 2006).

One mechanism that facilitates such shelf-deep ocean exchange in the Western Mediterranean is dense shelf water cascading (DSWC). It is a gravity current associated to the shelf edge overflow and down-slope sinking of continental shelf waters due to their excess density gained by cooling and/or evaporation (Ivanov et al., 2004). The Gulf of Lion $(\mathrm{GoL})$ is one of the few regions in the Mediterranean where this phenomenon takes place (Durrieu de Madron et al., 2005; Canals et al., 2009), with intense events occurring in a subdecadal scale. Various studies carried out in the GoL have documented the rapid export of sediment from the shelf and upper slope to deeper environments by intense

Published by Copernicus Publications on behalf of the European Geosciences Union. 
DSWC events occurring in winter 2004/05 (Bourrin et al., 2008; Canals et al., 2006; Puig et al., 2008; Ulses et al., 2008a) and winter 2005/06 (Sanchez-Vidal et al., 2008). Besides lateral (cross-slope) transport of material, the particle fluxes from open-ocean surface waters supply benthic sediments with fresh marine organic matter (Heussner et al., 2006). The temporal coincidence of DSWC and high pelagic fluxes seems to be responsible for the effective transfer of fresh marine organic matter towards deeper parts of the basin (Fabres et al., 2008; Sanchez-Vidal et al., 2009).

In this paper we evaluate the behavior and characteristics of settling particulate matter collected during the HERMES (Hotspot Ecosystems Research on the Margins of European Seas) project along the Lacaze-Duthiers and Cap de Creus canyons and the adjacent southern open slope from October 2005 to October 2006. Because an intense DSWC event took place and was registered by all sediment traps we have the opportunity to assess the impact of DSWC on particle fluxes along and across the slope. Concretely, we will analyze the spatial and temporal variability of the total mass fluxes and the variations in its organic matter, opal, calcium carbonate and siliciclastic contents.

\section{Study area and oceanographic settings}

The GoL margin is located in the Western Mediterranean and extends from Cap Croisette in the northeast to Cap de Creus in the southwest (Fig. 1). It is a wide, progressive margin incised by numerous submarine canyons extending down to the Algero-Balearic basin. The continental shelf is feded by different watersheds (Fig. 1): in the northeast, the Rhône River contributes to more than $90 \%$ of the total annual liquid and solid inputs of the rivers discharging to the Gulf of Lion mainly during the snowmelt in spring (Bourrin et al., 2006), whereas the southwestern rivers Hérault, Orb, Aude and Têt are subjected to a Mediterranean regime with short and intense flash-flood events (Serrat et al., 2001).

Sea surface circulation is characterized by the anticlockwise flow of modified Atlantic waters that form the Northern Current (Fig. 1). Its structure changes seasonally, becoming thicker and narrower and flowing closer to slope with maximum flow during the winter season (Millot, 1999). The Northern Current is associated to a permanent shelf-slope density front separating shelf and open-sea waters. Its position and meandering is suggested to significantly influence shelf-slope exchanges (Flexas et al., 2002) and organic carbon export (Van Wambeke et al., 2002). The Northern Current also controls the GoL primary production distribution, separating shelf waters directly influenced by the Rhône river from offshore waters with a clear seasonality in surface and deep chlorophyll $a$ concentrations, as revealed by both in situ measurements (Lefevre et al., 1997) and satellite images (Bosc et al., 2004). Main biological features identified in the southwestern GoL are spring mesotrophy when blooms

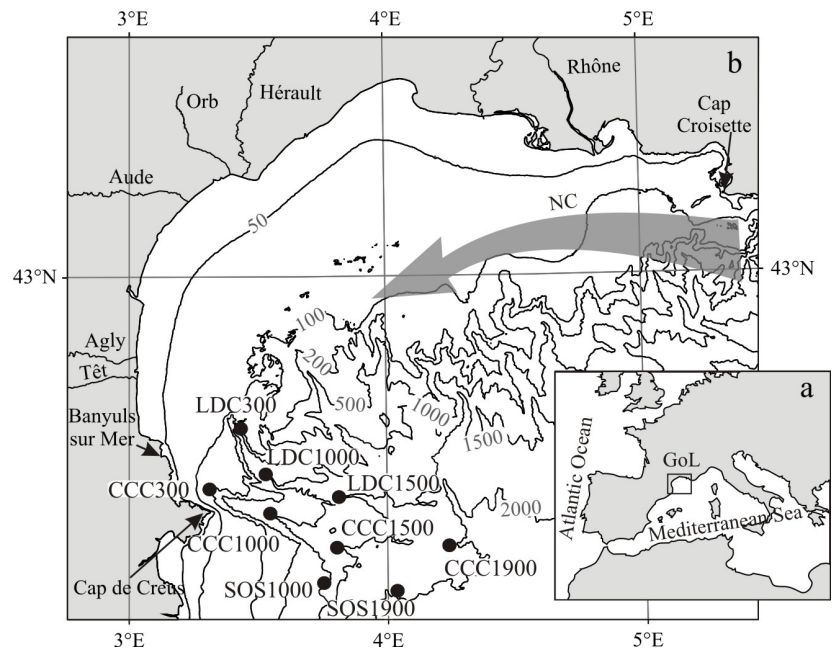

Fig. 1. (a) Location of the Gulf of Lion (GoL) in the Western Mediterranean Sea and (b) sediment trap mooring stations (black dots) along the tree transects studied: Lacaze-Duthiers Canyon (LDC), Cap de Creus Canyon (CCC), and their Southern Open Slope (SOS). Superficial main oceanic circulation is represented by the Northern Current (NC, grey arrow).

develop (Vidussi et al., 2000) and summer stratified oligotrophic waters followed by autumn blooms (Marty et al., 2008). When winter meteorological conditions are severe, long-lasting cold and dry northerly winds affecting the GoL region induce coastal and open-ocean convection, and both contribute to the renewal of the Western Mediterranean Deep Water (Bethoux et al., 1999; Fuda et al., 2000).

Within that context, sedimentary processes in the Gulf of Lion's continental shelf and slope have been the principal issue of several projects and are nowadays well understood. Fine sediments on the continental shelf are advected by the mean anticlockwise near-bottom flow, and exit the shelf through the westernmost submarine canyons mainly during E and SE winter storm events and DSWC (Palanques et al., 2006), resulting in an annual inventory budget on the shelf essentially equal to cero (Courp et al., 1990). Submarine canyons represent the preferential pathway (Monaco et al., 1990), as the shelf edge incision interacts with the bottom flow and funnel shelf water and material basinward. Significant increase of near-bottom transport of sediment were detected when storm-induced downwelling couples with DSWC, transporting resuspended sediments through the westernmost canyons as bottom turbidity layers (Palanques et al., 2006; Bonnin et al., 2008) and eroding canyon floor sediments (Canals et al., 2006; Puig et al., 2008). 


\section{Material and methods}

\subsection{Experimental design and data recovery}

Nine instrumented moorings were deployed in 3 different transects along the axes of the Lacaze-Duthiers and Cap de Creus canyons (LDC and CCC, respectively) at upper canyon $(300 \mathrm{~m})$, middle canyon $(1000 \mathrm{~m})$ and lower canyon $(1500 \mathrm{~m})$ and at canyon mouth were both canyons converge $(1900 \mathrm{~m})$, and along the southern open slope (SOS) at 1000 and $1900 \mathrm{~m}$ water depth (Fig. 1). The sampling period was from mid October 2005 to late October 2006 with a maintenance turnaround and sample recovery in mid April 2006. Each mooring was equipped with a PPS3 Technicap sequential sampling sediment trap (12 collecting cups, $0.125 \mathrm{~m}^{2}$ opening and $2.5 \mathrm{height} / \mathrm{diameter}$ aspect ratio for the cylindrical part) at $30 \mathrm{~m}$ above bottom and an Aanderaa current meter (RCM7/8/9) at $5 \mathrm{~m}$ above the bottom. In addition, the LDC1000 station included an extra trap-currentmeter pair at $500 \mathrm{~m}$ above the bottom (LDC1000-500 mab). Sampling intervals were set at 15 days for traps and 30 min for current meters. The receiving cups of the traps were filled up before deployment with a buffered 5\% (v/v) formaldehyde solution in $0.45 \mu \mathrm{m}$ filtered seawater. Failure of the sediment trap rotating motor resulted in the absence of samples during the first six months at the CCC 300 station and during two months at the LDC1000 station. In addition, early January 2006 sediment sampling bottle at the CCC1000 station overfilled and the excess material probably entered into the following cup during the rotation of the carrousel, so consecutive flux values are respectively under and overestimations.

\subsection{Sediment trap efficiency}

The general patterns of flux derived from traditional sediment traps are considered to be reasonable even it is known the uncertainties associated to trap hydrodynamics, swimmer intrusion and solubilisation processes that may bias the particle fluxes (Gardner et al., 1997; Buesseler et al., 2007 and references therein). The perturbation of the horizontal flow due to the presence of the trap is supposed to cause biases in the collection of particles. The efficiency is suggested to be a function of the trap design, the current velocity and the characteristics of the settling particles (Butman et al., 1986). The PPS3 sediment traps used in the experiment present an aspect/ratio that has been suggested that minimize the tilting (Heussner et al., 1990). Indeed, Bonnin et al. (2008) examined how the current velocity affected their PPS3 sediment traps by looking at pressure sensors on the currentmeters above the traps. They concluded that the tilt of the traps was around $15^{\circ}$ during high strong current episodes (up to $80 \mathrm{~cm} \mathrm{~s}^{-1}$ ), which would not affect significantly the collection efficiency of particle fluxes. However, under most flow conditions, most particles are not collected as a result of passive sinking, but by means of a water-exchange turbu- lent process in the mouth of the trap (Gardner, 1980; Butman, 1986). Several works have approached the hydrodynamic bias issue in a different ways, but the conditions under which the trapping biases become important are still poorly constrained (Buesseler at al., 2007). Among users of PPS3 sediment traps (e.g. Carbonne, 1991; Heussner et al., 1999) it is common to adopt a $15 \mathrm{~cm} \mathrm{~s}^{-1}$ limit for PPS 3 trap collecting efficiency. Other authors, such as Fabres et al. (2002), cut down that limit to a more conservative $12 \mathrm{~cm} \mathrm{~s}^{-1}$ threshold. Given the implicit limitations and uncertainties of sediment traps in quantifying downward matter fluxes, especially when sampling under high flow speeds as those reached during DSWC events, the results obtained from the traps and hereafter presented should be regarded as semi-quantitative data.

The intrusion of swimmers may also affect the particle flux. Sediment trap samples collected during our study were wet-sieved through a $1 \mathrm{~mm}$ nylon mesh in order to retain the largest organisms, which were not very abundant. Swimmers smaller than $1 \mathrm{~mm}$ were manually removed under a dissecting microscope using fine tweezers. In addition, physicalchemical processes such as the dissolution of biominerals or organic aggregates can also bias the particle flux of different compounds (Antia et al., 2005). The poisoning solution used in this study appears to be the most suitable compromise in terms of effectiveness and prevention of swimmer fragmentation (Heussner et al., 1990; Lee et al., 1992; Buesseler et al., 2007), even precluding DOC/DON measurements in supernatant.

\subsection{Sample treatment and analytical procedures}

After recovering, samples were stored in dark at $2-4{ }^{\circ} \mathrm{C}$ until they were processed in the laboratory according to the procedure described by Heussner et al. (1990). Samples were (i) repeatedly split into aliquots using a high precision peristaltic pump robot to obtain $10-20 \mathrm{mg}$ sub-samples, (ii) filtered through glass-fibre pre-weighted filters for carbon and nitrogen analysis and $0.45 \mu \mathrm{m}$ pore size cellulose membranes for total mass determination and biogenic $\mathrm{Si}$ analysis, (iii) rinsed with distilled water and, finally, (iv) dried at $40^{\circ} \mathrm{C}$ during $24 \mathrm{~h}$ for dry weight determination. The precision of mass estimates, as measured by the coefficient of variation was $4.1 \%$.

Total and organic carbon, and total nitrogen contents were measured using an elemental analyzer (EA Flash series 1112 and NA 2100). Samples for organic carbon analysis were first decarbonatated using repeated additions of $100 \mu \mathrm{l} 25 \%$ $\mathrm{HCl}$ with $60^{\circ} \mathrm{C}$ drying steps in between until no effervescence occurred. Organic matter (OM) content has been estimated as twice the total organic carbon content, and carbonate content was calculated assuming all inorganic carbon is contained within the calcium carbonate $\left(\mathrm{CaCO}_{3}\right)$ fraction, thus using the molecular mass ratio 100/12. Uncertainties were lower than $0.1 \%$ as determined from replicates of the 
certified estuarine sediment MESS-1. Biogenic Si was analyzed using a two-step extraction with $0.5 \mathrm{M} \mathrm{Na}_{2} \mathrm{CO}_{3}(2.5 \mathrm{~h}$ each) separated after filtration of the leachate. Inductive Coupled Plasma Atomic Emission Spectroscopy (ICP-AES) was used to analyze $\mathrm{Si}$ and $\mathrm{Al}$ contents in both leachates, and a correction of the $\mathrm{Si}$ of the first by the $\mathrm{Si} / \mathrm{Al}$ relation of the second one was applied to obtain the opaline Si concentration (Fabres et al., 2002). Corrected Si concentrations were transformed to opal after multiplying by a factor of 2.4 (Mortlock and Froelich, 1989). Analytical precision of opal measurements was $4.5 \%$. The siliciclastic fraction was calculated assuming $\%$ siliciclastic $=100-\left(\% \mathrm{OM}+\% \mathrm{CaCO}_{3}+\%\right.$ opal $)$. Grain size analysis of samples was performed after removal of organic matter with $10 \% \mathrm{H}_{2} \mathrm{O}_{2}$ on a Coulter LS 230 Laser Particle Size Analyzer.

\subsection{Forcing conditions}

Daily fluvial discharges $\left(\mathrm{m}^{3} \mathrm{~s}^{-1}\right)$ of the Rhône and the southwestern rivers (Hérault, Orb, Aude, and Têt) were obtained from Compagnie Nationale du Rhône and the Banque $H Y D R O$ of the French Ministry of Environment. Open ocean chlorophyll $a(\mathrm{chl} a)$ concentration $\left(\mathrm{mg} \mathrm{m}^{-3}\right)$ recorded by the Sea-viewing Wide Field-of-view Sensor (SeaWiFS) was obtained from the GES-DISC Interactive Online Visualization ANd aNalysis Infrastructure (GIOVANNI) at the NASA's Goddard Earth Sciences (GES) Data and Information Services Center (DISC). From OBPG SeaWiFS 8-Day Global 9-km time series, points with maximum resolution of 0.1 degree that cover our study stations were defined and mean temporal evolution of chl $a$ was obtained. Surface ( $3 \mathrm{~m}$ of water depth) coastal chl $a$ data was obtained from the SOLA monitoring station, located $1 \mathrm{~km}$ off Banyuls sur Mer and provided by Service d'Observation en Milieu LIToral (SOMLIT). Finally, significant wave heights H1/3 (m) data from the Sète wave buoy offshore station was provided by the Centre d'Etudes Maritimes et Fluviales.

\section{Results}

\subsection{River, waves and $\mathrm{Chl} a$ measurements}

The Rhône river main discharge during the monitored period (October 2005 to October 2006) lasted from mid February 2006 to the end of May 2006, with basal discharge of $1000 \mathrm{~m}^{3} \mathrm{~s}^{-1}$ and a maximum peak recorded in early April 2006 of $4165 \mathrm{~m}^{3} \mathrm{~s}^{-1}$. In contrast, southwestern rivers showed episodic water discharge pulses in autumn and winter, peaking in mid November 2005 and at the very end of January 2006 to $1390 \mathrm{~m}^{3} \mathrm{~s}^{-1}$ and $2923 \mathrm{~m}^{3} \mathrm{~s}^{-1}$, respectively (Fig. 2a). Coastal chl $a$ concentration was high form middle February to middle April 2006, with a major concentration peak of the pigment during early March $\left(4.2 \mathrm{mg} \mathrm{m}^{-3}\right)$. Offshore, the maximum concentrations (up to $2 \mathrm{mg} \mathrm{m}^{-3}$ ) were reached at the end of March and mid April 2006
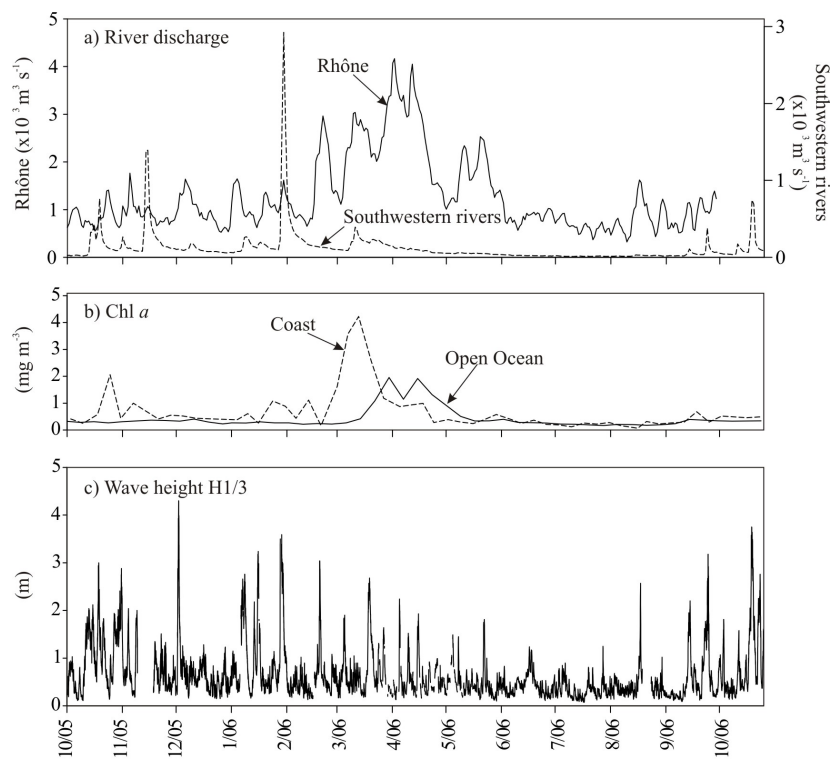

Fig. 2. (a) Daily fluvial discharges $\left(\mathrm{m}^{3} \mathrm{~s}^{-1}\right)$ of the Rhône and the Southwestern rivers (Hérault, Orb, Aude, and Têt), (b) mean chlorophyll $a$ (chl $a$ ) concentration $\left(\mathrm{mg} \mathrm{m}^{-3}\right)$ recorded at coastal station and open ocean and (c) significant wave Heights H1/3 (m) recorded at the Sète wave buoy offshore station.

(Fig. 2b). Minimum chl $a$ concentrations ( 0.07 at coastal site and around $0.2 \mathrm{mg} \mathrm{m}^{-3}$ at open ocean) were recorded during summer months. In addition, a weak increase of chl $a$ concentration was detected in September 2006 at both locations and during autumn 2005 at the coastal zone. Significant wave heights $(\mathrm{H} 1 / 3)$ were recorded during the experiment period, with an up to $4 \mathrm{~m}$ peak reached in early December 2005 and up to $2.5 \mathrm{~m}$ in January 2006 (Fig. 2c). Furthermore, spring and autumn were periods of recurrent wave height increases.

\subsection{Near-bottom temperature and currents measurements on the slope}

Current speed, temperatures and directions at $5 \mathrm{~m}$ above the bottom recorded by the current meters display two clearly different periods (Fig. 3). From January to March 2006 several pulses of maximum current speeds (punctual peaks of up to $80 \mathrm{~m} \mathrm{~s}^{-1}$ at the CCC 300 station) fitted along canyons axis and along slope were recorded. These currents were associated with a strong temperature anomaly (i.e. $-2.4{ }^{\circ} \mathrm{C}$ at the CCC300 station) which is the direct evidence of the occurrence of DSWC. Maximum speeds were reached in January and March 2006. This intense DSWC event was the last up to date recorded, and followed those that occurred in winters 1998/99 (Bethoux et al., 2002) and 2004/05 (Canals et al., 2006; Puig et al., 2008). At the canyon heads instabilities remained until mid July 2006. Increases in current speed and temperature were detected in autumn 2005 and 2006. At lower canyon, canyon mouth and open slope stations, current 
a) Current speed and temperature

b) Current direction
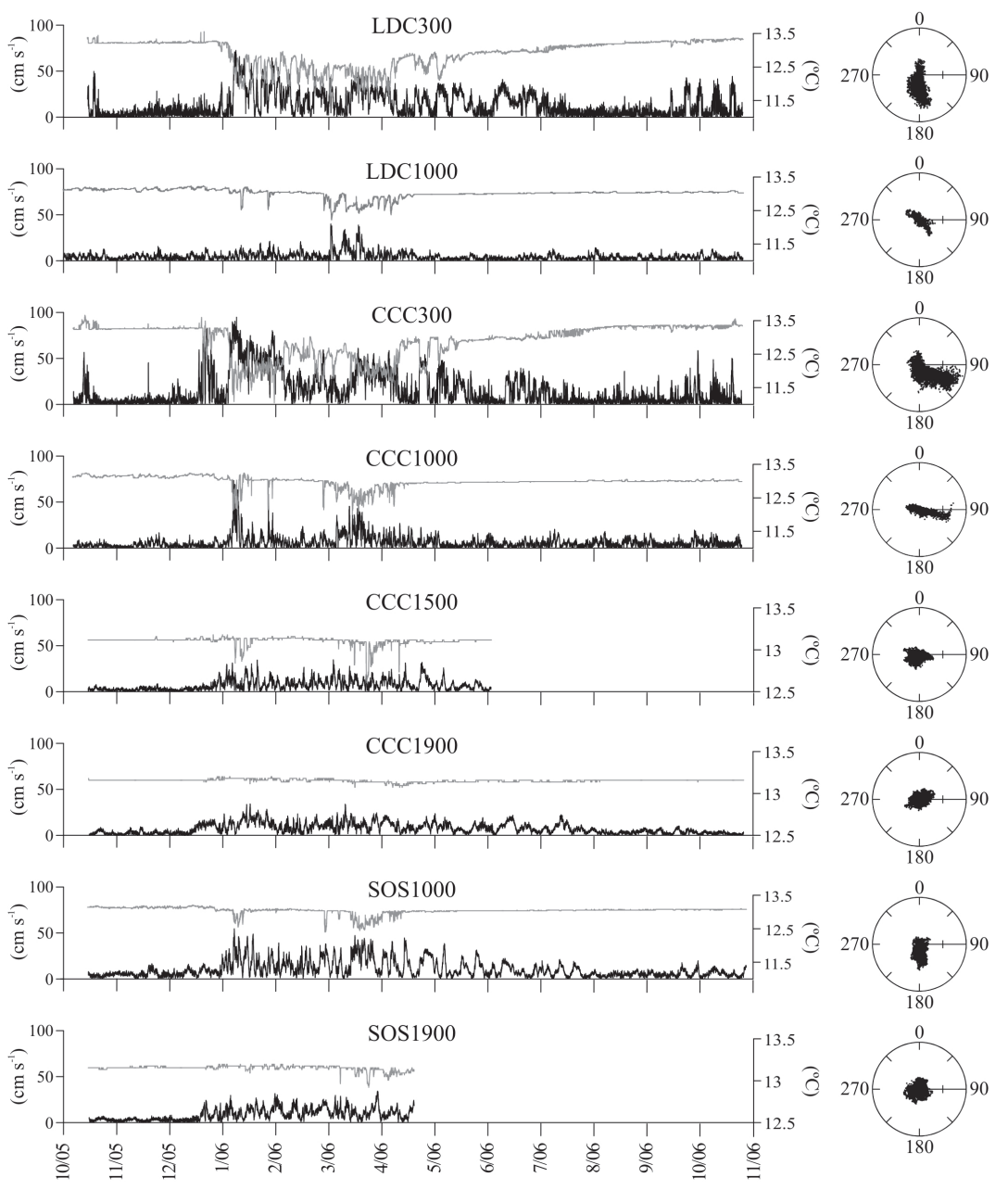

Fig. 3. (a) Current speed $\left(\mathrm{cm} \mathrm{s}^{-1}\right)$ and temperature $\left({ }^{\circ} \mathrm{C}\right)$ and (b) current directions as a function of the speed (radius limits are $0-100 \mathrm{~cm} \mathrm{~s}^{-1}$ ) recorded at $5 \mathrm{mab}$ at each station location (note different temperature axis scales).

velocities and temperatures did not stabilized until August 2006.

\subsection{Spatial and temporal variability of downward particle fluxes}

Mean total mass flux show a decreasing off-shelf trend (Table 1) with greater values inside canyons compared to the open slope. Values ranged between $11.7 \mathrm{~g} \mathrm{~m}^{-2} \mathrm{~d}^{-1}$ in CCC $1000 \mathrm{~m}$ station down to $0.7 \mathrm{~g} \mathrm{~m}^{-2} \mathrm{~d}^{-1}$ in the CCC1900 station. Mean flux at the upper open slope (SOS1000) was lower $\left(3.4 \mathrm{~g} \mathrm{~m}^{-2} \mathrm{~d}^{-1}\right)$ when compared with the stations at the same depth inside the canyons $\left(11.7\right.$ and $6.7 \mathrm{~g} \mathrm{~m}^{-2} \mathrm{~d}^{-1}$ at CCC1000 and LDC1000, respectively). In contrast, the deep open slope SOS1900 station recorded higher mean flux values $\left(0.8 \mathrm{~g} \mathrm{~m}^{-2} \mathrm{~d}^{-1}\right)$ than CCC1900 station at the confluence of both canyons $\left(0.7 \mathrm{~g} \mathrm{~m}^{-2} \mathrm{~d}^{-1}\right)$.
Particle flux time series at all stations display high temporal variability (Table 1, Fig. 4). At the CCC1000 station there was a 90 -fold increase in total mass flux in early January $2006\left(90.1 \mathrm{~g} \mathrm{~m}^{-2} \mathrm{~d}^{-1}\right.$, maximum flux recorded) respect to late July $2006\left(1.0 \mathrm{~g} \mathrm{~m}^{-2} \mathrm{~d}^{-1}\right)$ (Fig. 4b). The main visible feature of the temporal variability is the total mass flux increase in January 2006 in most of the stations and the maintenance of high values during the following two months, until March-early April 2006, with the exception of LDC300. This maximum flux period (from January to March 2006) was characterized by two discrete peaks at most of the stations. The first particle flux peak was registered in early January 2006 (CCC1000, CCC1500 and SOS1000 stations), late January 2006 (LDC1000, LDC1000-500 mab, SOS1900) and early February 2006 (LDC1500 and CCC1900), and represented the maximum total mass flux at almost all stations except for the LDC1500 and CCC1900 stations, were the major particle fluxes were recorded during the second peak 
Table 1. Total mass (TM) flux $\left(\mathrm{g} \mathrm{m}^{-2} \mathrm{~d}^{-1}\right)$, main components (OM, opal, $\mathrm{CaCO}_{3}$ and siliciclasts) flux ( $\left.\mathrm{mg} \mathrm{m}^{-2} \mathrm{~d}^{-1}\right)$ and content $(\%)$ along the Lacaze-Duthiers Canyon, Cap de Creus Canyon and Southern Open Slope transects. Statistics presented are mean, maximum (Max) and minimum (Min). Mean flux has been calculated as time weighted flux, and mean concentration as flux weighted concentration following Heussner et al. (2006). * Data gaps, see Fig. 3.

\begin{tabular}{|c|c|c|c|c|c|c|c|c|c|c|}
\hline \multirow{2}{*}{ Station } & & \multirow{2}{*}{$\begin{array}{r}\text { TM } \\
\text { Flux }\end{array}$} & \multicolumn{2}{|c|}{$\mathrm{OM}$} & \multicolumn{2}{|c|}{ Opal } & \multicolumn{2}{|c|}{$\mathrm{CaCO}_{3}$} & \multicolumn{2}{|c|}{ Siliciclastic } \\
\hline & & & Flux & $\%$ & Flux & $\%$ & Flux & $\%$ & Flux & $\%$ \\
\hline \multirow[t]{3}{*}{ LDC300 } & Max & 18.1 & 637.7 & 8.2 & 207.2 & 3.7 & 5254.2 & 36.6 & 12116.9 & 71.6 \\
\hline & Min & 0.3 & 11.7 & 2.7 & 3.8 & 0.1 & 71.2 & 23.4 & 198.3 & 54.1 \\
\hline & Mean & 6.7 & 236.9 & 3.5 & 73.7 & 1.1 & 1964.5 & 29.3 & 4437.6 & 66.1 \\
\hline \multirow[t]{3}{*}{ LDC1000 (500 mab) } & Max & 11.2 & 354.1 & 10.9 & 351.9 & 10.0 & 3361.0 & 42.9 & 7410.6 & 68.6 \\
\hline & Min & 0.6 & 26.7 & 3.0 & 7.5 & 0.6 & 187.2 & 23.1 & 423.9 & 40.5 \\
\hline & Mean & 2.9 & 124.2 & 4.4 & 77.6 & 2.7 & 803.2 & 28.2 & 1848.1 & 64.8 \\
\hline \multirow[t]{3}{*}{ LDC1000* } & $\operatorname{Max}$ & 39.9 & 968.8 & 5.2 & 319.0 & 5.2 & 12124.0 & 30.7 & 26623.2 & 67.5 \\
\hline & Min & 1.8 & 67.5 & 2.3 & 19.1 & 0.4 & 566.7 & 25.9 & 1169.2 & 61.4 \\
\hline & Mean & 6.7 & 198.5 & 3.0 & 86.0 & 1.3 & 1967.4 & 29.6 & 4400.2 & 66.1 \\
\hline \multirow[t]{3}{*}{ LDC1500 } & Max & 11.9 & 417.5 & 10.7 & 270.9 & 10.8 & 3423.2 & 34.9 & 7827.6 & 65.8 \\
\hline & Min & $<0.1$ & 3.6 & 2.8 & 1.1 & 0.8 & 8.7 & 23.1 & 22.3 & 49.9 \\
\hline & Mean & 1.4 & 52.2 & 3.8 & 47.8 & 3.3 & 414.9 & 30.1 & 865.1 & 62.8 \\
\hline \multirow[t]{3}{*}{ СCC $300 *$} & Max & 20.0 & 524.4 & 6.3 & 293.8 & 3.5 & 5685.1 & 29.0 & 13535.9 & 67.7 \\
\hline & Min & 2.0 & 120.7 & 2.6 & 55.4 & 0.9 & 566.9 & 26.0 & 1287.1 & 63.4 \\
\hline & Mean & 7.0 & 245.9 & 3.5 & 113.2 & 1.6 & 1963.2 & 28.0 & 4680.8 & 66.8 \\
\hline \multirow[t]{3}{*}{ CCC 1000} & Max & 90.1 & 1489.2 & 7.3 & 333.3 & 9.0 & 25124.9 & 29.9 & 63321.0 & 73.1 \\
\hline & Min & 1.0 & 37.3 & 1.7 & 15.6 & 0.2 & 253.5 & 22.6 & 656.2 & 61.2 \\
\hline & Mean & 11.7 & 301.8 & 2.6 & 99.8 & 0.8 & 3262.8 & 27.8 & 8071.8 & 68.8 \\
\hline \multirow[t]{3}{*}{ CCC 1500} & Max & 6.3 & 200.8 & 19.0 & 200.5 & 13.1 & 1711.4 & 36.3 & 4297.8 & 68.6 \\
\hline & Min & $<0.1$ & 3.0 & 2.9 & 1.4 & 1.2 & 7.7 & 25.2 & 15.3 & 41.2 \\
\hline & Mean & 1.3 & 48.5 & 3.8 & 43.4 & 3.3 & 390.4 & 29.6 & 833.4 & 63.2 \\
\hline \multirow[t]{3}{*}{ CCC1900 } & Max & 3.2 & 119.5 & 13.9 & 88.5 & 10.4 & 1000.7 & 34.7 & 2001.5 & 63.4 \\
\hline & Min & $<0.1$ & 3.1 & 2.7 & 2.1 & 1.4 & 10.8 & 23.5 & 20.5 & 42.8 \\
\hline & Mean & 0.7 & 28.8 & 4.1 & 25.6 & 3.7 & 224.8 & 32.2 & 419.3 & 60.0 \\
\hline \multirow[t]{3}{*}{ SOS1000 } & Max & 34.1 & 796.6 & 8.6 & 148.6 & 11.5 & 9375.5 & 35.7 & 23764.1 & 69.7 \\
\hline & Min & 0.2 & 7.7 & 2.3 & 4.1 & 0.4 & 42.2 & 24.9 & 94.8 & 50.0 \\
\hline & Mean & 3.4 & 105.0 & 3.0 & 41.0 & 1.2 & 995.1 & 28.0 & 2405.3 & 67.8 \\
\hline \multirow[t]{3}{*}{ SOS1900 } & $\operatorname{Max}$ & 5.7 & 138.1 & 16.2 & 97.5 & 11.6 & 2022.5 & 39.7 & 3499.1 & 62.6 \\
\hline & Min & $<0.1$ & 1.2 & 2.4 & 2.4 & 1.4 & 12.5 & 25.0 & 16.8 & 34.8 \\
\hline & Mean & 0.8 & 32.7 & 3.8 & 32.0 & 3.4 & 306.4 & 33.1 & 551.3 & 59.6 \\
\hline
\end{tabular}

in late March 2006 (early April at SOS1900 m, and early May in LDC1000-500 mab). Total mass flux in the LacazeDuthiers upper canyon (LDC300) displayed an inverse behaviour, with fluxes decreasing from $14.0 \mathrm{~g} \mathrm{~m}^{-2} \mathrm{~d}^{-1}$ in late December 2005 down to a minimum of $0.3 \mathrm{~g} \mathrm{~m}^{-2} \mathrm{~d}^{-1}$ in early March 2006. In both upper canyon stations (LDC300 and $\mathrm{CCC} 300)$ maximum fluxes were reached during late summer (from late August) and autumn seasons (both 2005 and 2006), with values up to 18.1 and $20.0 \mathrm{~g} \mathrm{~m}^{-2} \mathrm{~d}^{-1}$, respectively.

\subsection{Trends in composition of settling particles}

Mean flux and concentrations of major constituents (OM, opal, $\mathrm{CaCO}_{3}$ and siliciclastic) are shown in Table 1. The siliciclastic component predominated at all stations, ranging from 59.5 to $68.8 \%$. Siliciclastic mean flux diminished from middle canyon and slope stations while increasing water depth, so relative content of non-siliciclastic components increased along the same direction. Concentration of OM varied from $3.5 \%$ at the upper canyons to $4.1 \%$ at the canyon mouth, and from $3.0 \%$ to $3.8 \%$ at the open slope transect. Opal and $\mathrm{CaCO}_{3}$ recorded almost the same off-margin increase. 


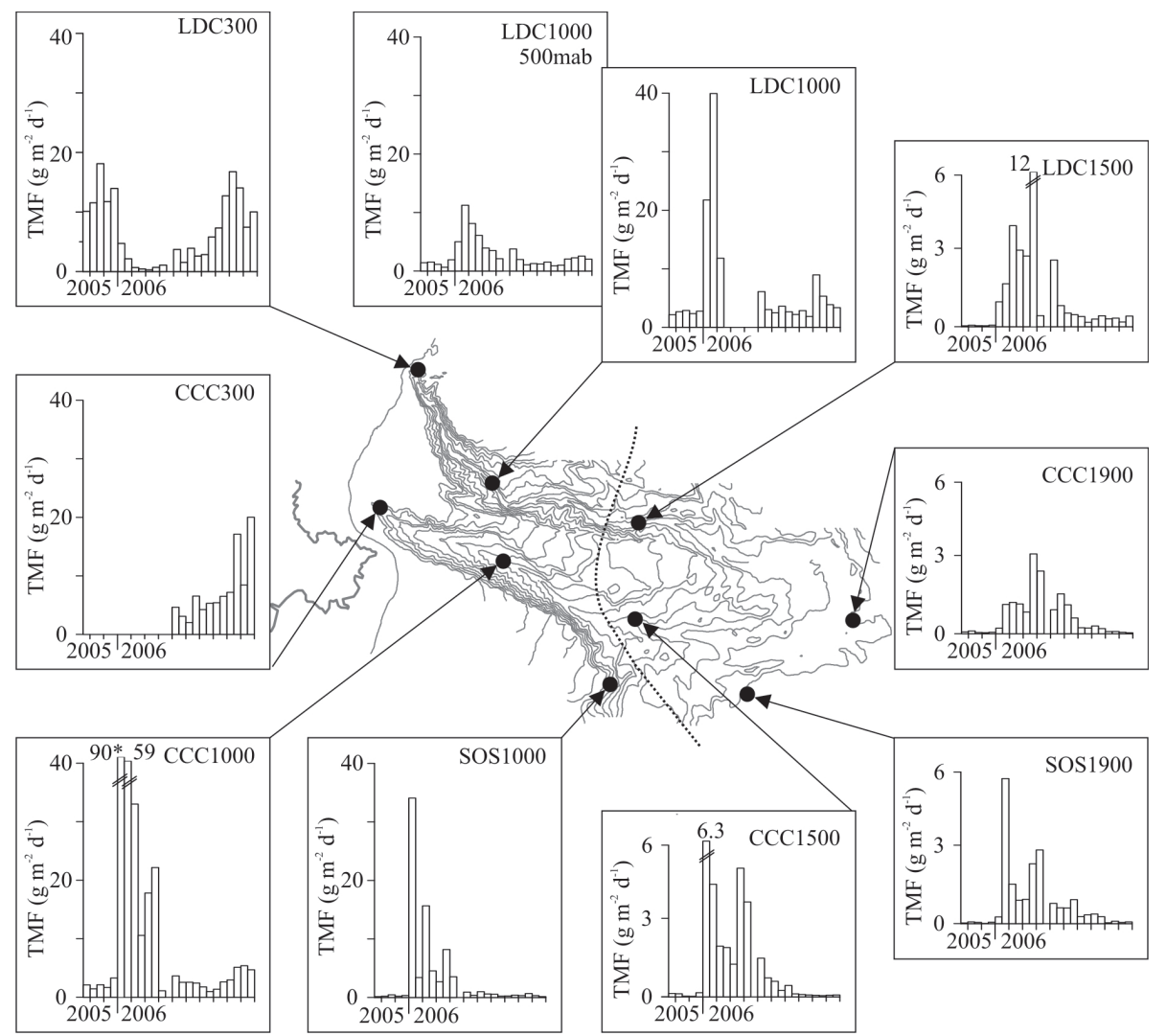

Fig. 4. Time series of total mass fluxes $\left(\mathrm{g} \mathrm{m}^{-2} \mathrm{~d}^{-1}\right)$ along transects studied: Lacaze-Duthiers Canyon (LDC), Cap de Creus Canyon (CCC) and Southern Open Slope (SOS), at different water depth stations. Contour every $100 \mathrm{~m}$ (note that dotted line separate stations with different scale of the TMF axis). * Overfilled.

Temporal variability of main constituents is quite evident, with main fluctuations recorded similarly in all traps during spring. During summer and autumn seasons peaks of biogenic components $\left(\mathrm{OM}\right.$, opal and $\left.\mathrm{CaCO}_{3}\right)$ were higher in lower canyon, canyon mouth and open slope stations (Fig. 5). Maximum OM concentrations were recorded during December 2005 and August 2006, with values up to 19.0\% at CCC1500, $16.2 \%$ at SOS1900 and $13.9 \%$ at CCC1900 (Fig. 5a). OM content reached minimum values during January 2006 at all stations and during autumn 2006 at upper canyon and middle canyon stations. Accordingly, minimum opal concentrations were recorded during JanuaryMarch 2006 at all stations except at both upper canyons, that were recorded during autumn 2005 (LDC300) and autumn 2006 (CCC300) (Fig. 5a, b). Several peaks in opal concentration were detected concomitantly at most of the stations (Fig. 5b), such as in May 2006 (recorded at all stations, maximum values up to $13.11 \%$ at the CCC1500 station), and early summer 2006 (up to $12.12 \%$ at the CCC1500 station, recorded at all stations except for both upper canyons). Punctual peaks of $\mathrm{CaCO}_{3}$ were detected in late summer-early autumn 2006, when SOS1900 reached the maximum carbonate content $(39.7 \%)$ similarly to SOS1000 (35.7\%).

\section{Discussion}

\subsection{Lateral transport of material by DSWC}

\subsubsection{Role of DSWC in canyons}

The arrival of massive amounts of material (up to $90 \mathrm{~g} \mathrm{~m}^{-2} \mathrm{~d}^{-1}$ at the middle Cap de Creus canyon) associated to strong temperature anomalies and increased current speeds (Fig. 3a) reveals that DSWC was the major physical driver of particle fluxes in the southwestern GoL during the monitored period. The occurrence of DSWC caused total mass flux to increase (Fig. 4) and to be dominated by the siliciclastic fraction (up to 63.3\%) (Fig. 6). Concomitantly, composition had the tendency to be constant (Fig. 6) indicating the downcanyon transport of homogenized material. Mean composition of the non-siliciclastic fraction was $30.0 \%$ of $\mathrm{CaCO}_{3}$, $3.2 \%$ of OM, and $1.5 \%$ of opal (Fig. 5), quite similar values than those reported by Heussner et al. (2006) during maximum fluxes over a 8-year period $\left(31-32 \% \mathrm{CaCO}_{3}, 2 \% \mathrm{OM}\right.$, and $1 \%$ opal), and close to the composition of the superficial sediments from the shelf and upper slope $\left(31 \% \mathrm{CaCO}_{3}, 1-\right.$ $4 \% \mathrm{OM}$, and opal nearly absent or below the detection limits, Roussiez et al., 2006). 

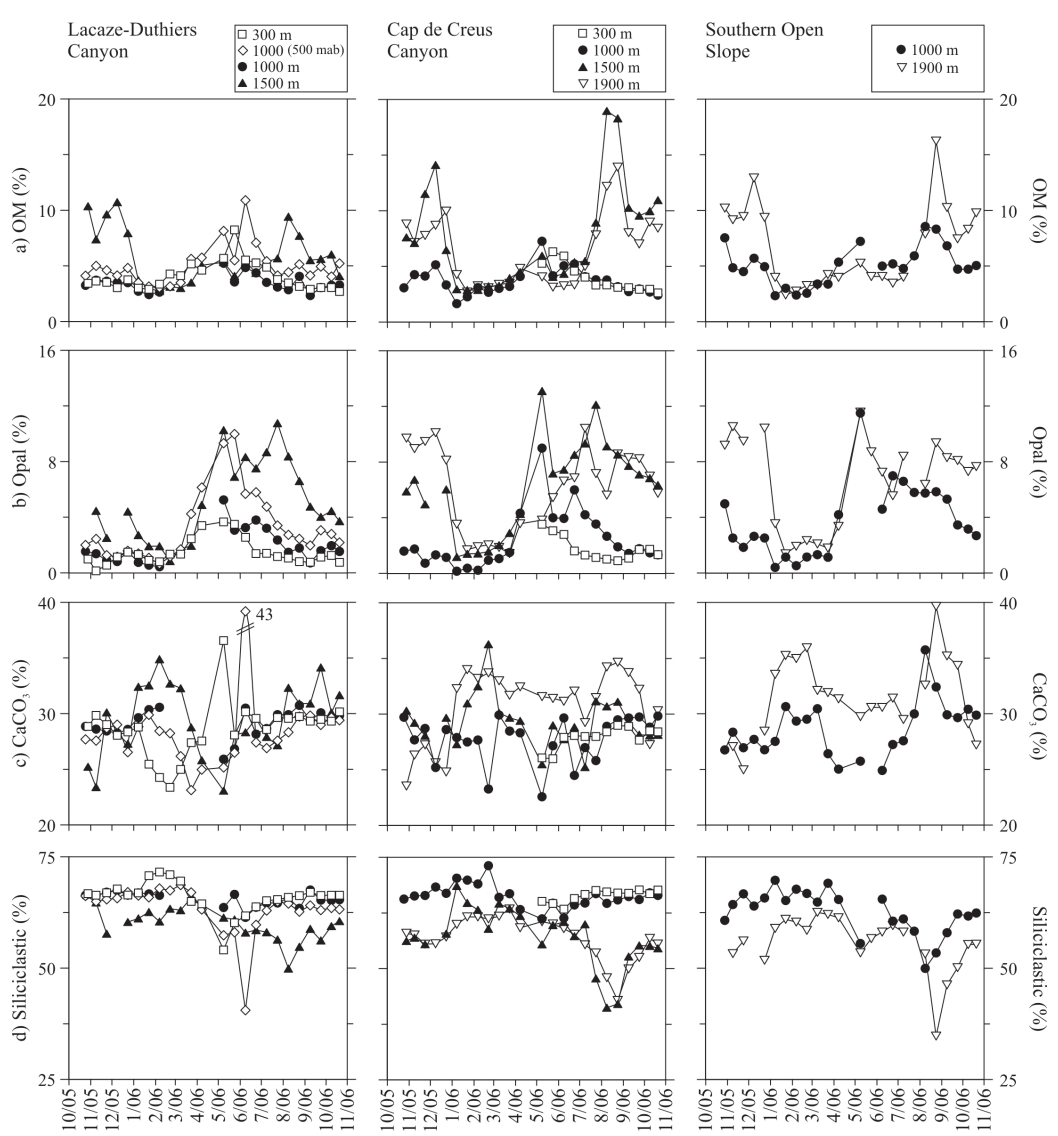

Fig. 5. Temporal evolution of (a) organic matter (OM), (b) opal, (c) calcium carbonate $\left(\mathrm{CaCO}_{3}\right)$, and (d) siliciclastic fractions, in the LacazeDuthiers Canyon (LDC), Cap de Creus Canyon (CCC) and Southern Open Slope (SOS) for different water depths stations: $300 \mathrm{~m}$ (white squares), $1000 \mathrm{~m}$ (black dots), $1000 \mathrm{~m}$ (500 mab) (white rhombus), $1500 \mathrm{~m}$ (black up triangles) and $1900 \mathrm{~m}$ (white down triangles).
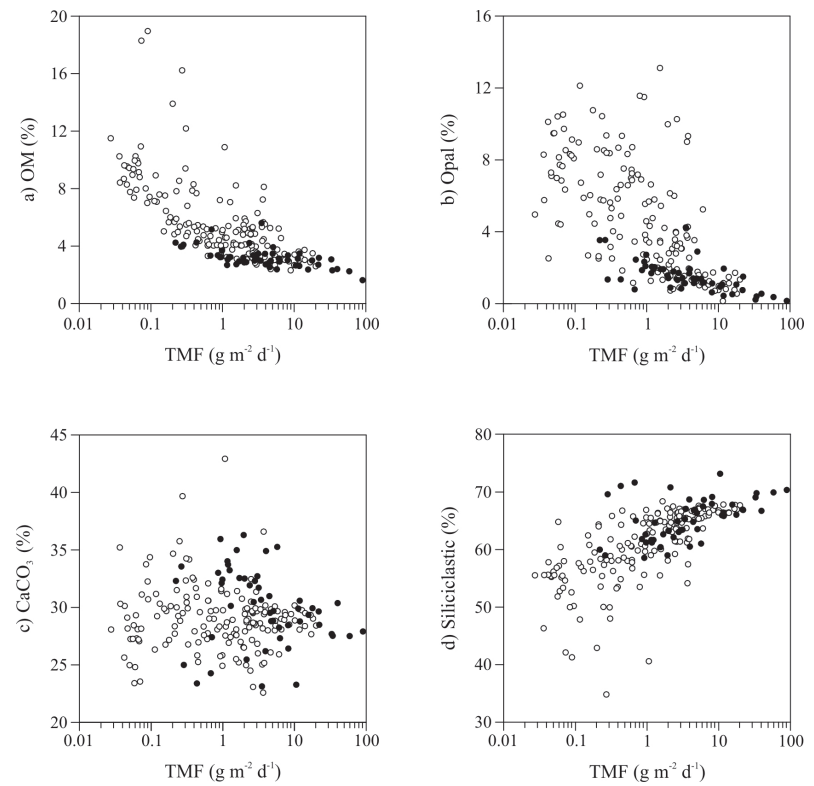

Fig. 6. Content of (a) organic matter (OM), (b) opal, (c) calcium carbonate $\left(\mathrm{CaCO}_{3}\right)$, and (d) siliciclastic versus total mass flux (TMF) $\left(\mathrm{g} \mathrm{m}^{-2} \mathrm{~d}^{-1}\right)$ for samples recovered during the main DSWC period (black dots) and out of the main DSWC period (white dots).
The large amount of mass settled during the main DSWC period represents up to $83.5 \%$ (CCC1000 station) of the total mass settled during the experiment (October 2005-October 2006) (Table 2). This represents a mass up to $3.5 \mathrm{~kg} \mathrm{~m}^{-2}$ at CCC1000 station and up to $1 \mathrm{~kg} \mathrm{~m}^{-2}$ in lower canyon and middle slope stations. Despite the dilution of the OM inside the siliciclastic material settled during the DSWC event, is during DSWC when higher mass of OM settles at all stations (Table 3). For the CCC1000 and SOS1000 station, for example, $75 \%$ of the total OM flux recorded over 1 year settled during the main DSWC period, which accounts up to $80.7 \mathrm{~g} \mathrm{~m}^{-2}$ at the CCC1000 station. Thus, the DSWC supposed an extra input of OM in a very short time period (3 months). The arrival of this OM highly diluted in the siliciclastic matrix may have profound implications for deep ecosystems, which will depend on the capacity of benthic organisms to adapt at the changing environmental conditions (current velocity, water temperature, sedimentation rate, OM concentration, etc.). It has also to be considered that coastal phytoplanktonic blooms were developing during winter time (Fig. 2b) and shelf material transported downward may have carried its signal, as suggested Sanchez-Vidal et al. (2009) by looking at the isotopic composition of organic matter. Indeed, they report increased marine organic 
matter contribution at the end of the DSWC period. Likewise, Fabres et al. (2008) concluded that the synchronic bloom and 2003/04 DSWC minor event enhanced the downcanyon export of a relatively fresh OM. The quality of the OM transferred by the DSWC may depend on the availability of OM from the different sources when it is taking place (see Sect. 5.2).

There are noticeable differences between the Cap de Creus and Lacaze-Duthiers canyons concerning the first maximum peak of total mass flux. At Cap de Creus middle and lower canyon stations the total mass flux peak was registered in early January 2006. At Lacaze-Duthiers canyon it was registered at the end of January at middle canyon station and in early February 2006 at the lower canyon station (Fig. 4), one month later than the equivalent station in the Cap de Creus canyon (CCC1500). Those differences are likely related to the lower current speeds and temperature anomalies along the Lacaze-Duthiers canyon. Recent studies have described the different impact of DSWC on sediment transfer through both canyons (Heussner et al., 2006; Palanques et al., 2006; Ogston et al., 2008). Current meter and turbidity indicate that the 2003/04 minor events transferred one order of magnitude more sediment through the Cap de Creus canyon than through the Lacaze-Duthiers canyon (Palanques et al., 2006). The same trend was observed during the 2004/05 DSWC event, and was related to higher duration and strength of cascading flows in the CCC due to the narrowing of the shelf towards the Cap de Creus and differences in upper canyon morphology (Ogston et al., 2008).

Even material was relatively homogenized, compositional change can be discerned as material was transported downslope, with enrichment in $\mathrm{OM}$, opal and $\mathrm{CaCO}_{3}$, and an impoverishment of the siliciclastic fraction (Fig. 7). This cross slope geochemical gradient of the settling organic particles and the fining of particle size with increasing depth are associated to the current regime, as was pointed by Sanchez-Vidal et al. (2008) for the first DSWC peak in January 2006. The sediment trap located at $500 \mathrm{~m}$ above bottom at the LacazeDuthiers middle canyon registered also the event, with mean total mass flux of $6.3 \mathrm{~g} \mathrm{~m}^{-2} \mathrm{~d}^{-1}$ during the main DSWC period. Similarly to the sediment trap located at $30 \mathrm{~m}$ above bottom, the maximum peak at $500 \mathrm{~m}$ above the bottom was at the end of January 2006, but showed lower $\mathrm{CaCO}_{3}$ and siliciclastic contents (Fig. 5). Cascading waters loaded with particulate material reached $500 \mathrm{~m}$ of water depth, probably as an intermediate nepheloid layer detached from the shelf or around the upper slope and canyon regions.

The general mass flux increase during the DSWC event was not detected at Lacaze-Duthiers upper canyon station (LDC300), where mean mass flux during the main DSWC period was lower than the rest of the year (1.5 and $8.5 \mathrm{~g} \mathrm{~m}^{-2} \mathrm{~d}^{-1}$ respectively, see Table 2). In fact, near-bottom settling fluxes concentrated down canyon as indicates the mass flux increase from $3.5 \mathrm{~g} \mathrm{~m}^{-2} \mathrm{~d}^{-1}$ at the head of the canyon to $24.5 \mathrm{~g} \mathrm{~m}^{-2} \mathrm{~d}^{-1}$ at the $1000 \mathrm{~m}$ depth station, sug-
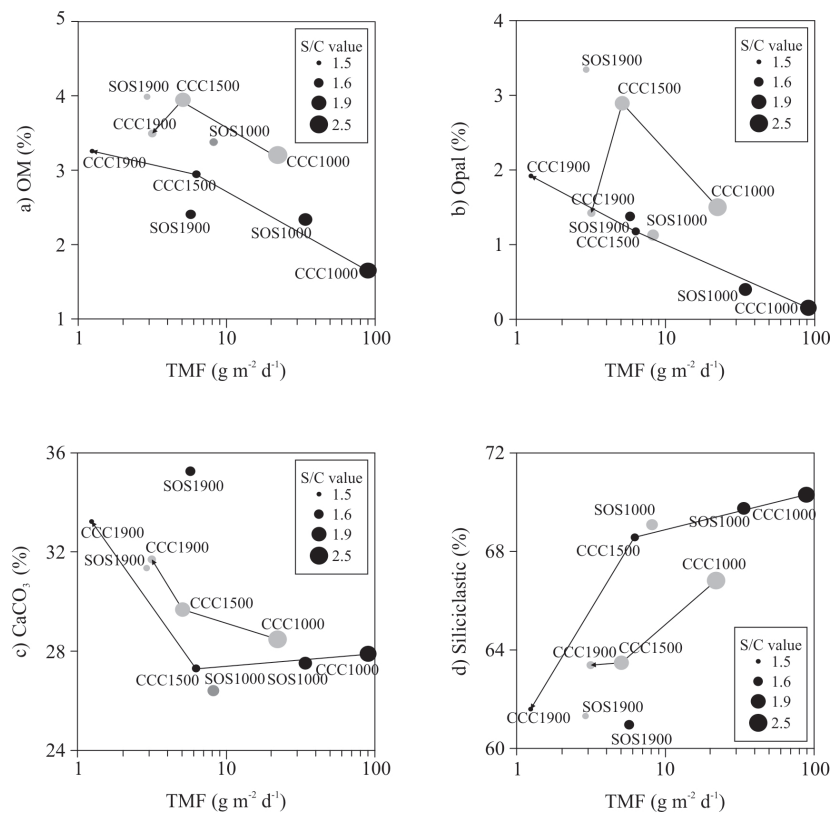

Fig. 7. Content of (a) organic matter (OM), (b) opal, (c) calcium carbonate $\left(\mathrm{CaCO}_{3}\right)$, and (d) siliciclastic versus total mass flux (TMF) $\left(\mathrm{g} \mathrm{m}^{-2} \mathrm{~d}^{-1}\right)$ of the samples recovered during the maximum arrival of material of each DSWC pulse (first pulse (black dots) and second one (grey dots)). Arrows represent the along Cap de Creus transect. Size of the dot represents the value of the silt/clay ratio (S/C).

gesting that upper canyons acted as bypass areas of material during the period of strong downcanyon currents. Even though no data is available from the Cap de Creus upper canyon station, a similar behavior was found in this canyon during the winter 2004/05 DSWC event, where sedimentary patterns and suspended sediment concentrations evidenced resuspension by strong downcanyon currents of the material temporally deposited in the upper canyon section (DeGeest et al., 2008; Puig et al., 2008). The composition of the material settled during the main DSWC period at Lacaze-Duthiers upper canyon station had low $\mathrm{CaCO}_{3}$ content (Fig. 5), extremely high $\mathrm{C} / \mathrm{N}$ ratio and a terrestrial isotopic signal of OM (Sanchez-Vidal et al., 2008). The concomitant wave height and southwestern river flow increase in late January 2006 (Fig. 2a, c) suggest the arrival of land-derived sediments, mainly from the Pyrenean rivers as suggested by the lower content in carbonates (Roussiez et al., 2006). Indeed, fast transport from the shelf to the slope was suggested by Monaco (1990) inside Lacaze-Duthiers canyon and by Palanques et al. (2008) during the 2004/05 event when storms and DSWC coincide.

\subsubsection{Impact of DSWC on the open slope}

At upper open slope station (SOS1000) total mass fluxes increased from late December $2005\left(0.3 \mathrm{mg} \mathrm{m}^{-2} \mathrm{~d}^{-1}\right)$ to early 
Table 2. Flux $\left(\mathrm{g} \mathrm{m}^{-2} \mathrm{~d}^{-1}\right)$, total mass (TM) $\left(\mathrm{g} \mathrm{m}^{-2}\right)$ and relative contribution of settled mass to (\%) during the main Dense Shelf Water Cascading (DSWC) period (January, February and March) and out of the main DSWC period recovered at each station. ${ }^{*}$ Data gaps, see Fig. 3.

\begin{tabular}{lrrrrrr}
\hline & \multicolumn{3}{c}{ Main DSWC period } & \multicolumn{3}{c}{ Out main DSWC period } \\
Station & Flux & TM & $\%$ & Flux & TM & $\%$ \\
\hline LDC300 & 1.5 & 134.5 & 5.7 & 8.5 & 2208.3 & 94.3 \\
LDC1000 (500 mab) & 6.3 & 568.9 & 56.0 & 1.7 & 446.8 & 44.0 \\
LDC1000* & 24.5 & 1102.2 & 56.0 & 3.5 & 866.9 & 44.0 \\
LDC1500 & 4.1 & 366.2 & 76.2 & 0.4 & 114.3 & 23.8 \\
CCC300* & N.D. & N.D. & - & 6.5 & 1232.5 & - \\
CCC1000 & 38.7 & 3487.0 & 83.5 & 2.6 & 691.0 & 16.5 \\
CCC1500 & 3.5 & 315.8 & 71.7 & 0.5 & 124.6 & 28.3 \\
CCC1900 & 1.3 & 117.3 & 48.1 & 0.5 & 126.5 & 51.9 \\
SOS1000 & 11.4 & 1028.6 & 86.6 & 0.6 & 158.8 & 13.4 \\
SOS1900 & 2.0 & 177.3 & 60.6 & 0.4 & 115.2 & 39.4 \\
\hline
\end{tabular}

Table 3. Total Mass (TM) $\left(\mathrm{g} \mathrm{m}^{-2}\right)$ settled of $\mathrm{OM}, \mathrm{Opal}, \mathrm{CaCO}_{3}$ and Siliciclastic during the main DSWC period and percentage that represents respect the total experiment period. ${ }^{*}$ Data gaps, see Fig. 3.

\begin{tabular}{|c|c|c|c|c|c|c|c|c|}
\hline \multirow[b]{2}{*}{ Station } & \multicolumn{2}{|c|}{$\mathrm{OM}$} & \multicolumn{2}{|c|}{ Opal } & \multicolumn{2}{|c|}{$\mathrm{CaCO}_{3}$} & \multicolumn{2}{|c|}{ Siliciclastic } \\
\hline & $\mathrm{TM}$ & $\%$ & TM & $\%$ & TM & $\%$ & TM & $\%$ \\
\hline LDC300 & 4.4 & 5.3 & 1.7 & 6.6 & 36.5 & 5.3 & 91.8 & 5.9 \\
\hline LDC1000 (500 mab) & 19.6 & 44.2 & 7.9 & 28.7 & 160.2 & 56.0 & 381.2 & 57.9 \\
\hline LDC1000* & 28.1 & 47.8 & 6.6 & 25.8 & 332.6 & 57.1 & 734.9 & 56.4 \\
\hline LDC1500 & 11.9 & 65.3 & 6.6 & 42.5 & 113.8 & 78.6 & 233.9 & 77.6 \\
\hline CCC300* & n.d. & n.d. & n.d. & n.d. & n.d. & n.d. & n.d. & n.d. \\
\hline CCC1000 & 80.7 & 75.1 & 15.8 & 44.5 & 968.0 & 83.3 & 2422.5 & 84.3 \\
\hline CCC1500 & 10.1 & 59.9 & 5.5 & 38.2 & 95.2 & 73.0 & 204.9 & 73.6 \\
\hline CCC1900 & 3.9 & 38.4 & 2.0 & 22.9 & 38.4 & 48.9 & 73.0 & 49.9 \\
\hline SOS1000 & 26.4 & 75.5 & 6.6 & 45.3 & 290.1 & 87.6 & 705.6 & 88.1 \\
\hline SOS1900 & 5.3 & 48.9 & 3.0 & 28.5 & 60.8 & 64.0 & 108.1 & 63.3 \\
\hline
\end{tabular}

January $2006\left(34.1 \mathrm{mg} \mathrm{m}^{-2} \mathrm{~d}^{-1}\right)$, following the same trend and at the same time than CCC1000 station (Fig. 4) with a $16 \mathrm{~h}$ time lag between the first flushing of cold water at $\mathrm{CCC} 1000$ and SOS1000 as indicate temperature records (Fig. 3a). While CCC1000 current-meter indicates a clearly along axis direction of the flow during DSWC, the direction of the water flow at the SOS1000 was mainly along slope (Fig. 3). Material settling during the first cascading pulse at both CCC1000 and SOS1000 stations was quite similar (Fig. 7). Indeed, closer than CCC1000 and CCC1500 stations. This suggests that during the first pulse the material was transported by cascading waters through the Cap de Creus canyon, probably covering the southern wall of the canyon (Ulses et al., 2008b), and was spread out of the Cap de Creus canyon where the canyon widens at the lower domain. Then, the material was transported southwards, impacting SOS1000 station. Probably, most of this material remained in suspension and was transported within the along shore current to distal areas. In fact, cascading waters have been detected offshore as anomalies in water mass properties (Bethoux et al., 2002; Lopez-Jurado et al., 2005; Font et al., 2007). Palanques et al. (2009) observed a strong increase of total mass flux in the open Northwestern Mediterranean Basin at $2350 \mathrm{~m}$ ( $250 \mathrm{~m}$ above bottom) clearly linked to the 2004/05 intense cascading event. In addition, Zúñiga et al. (2008) in their experiment in winter 2001/02 found an increase in particle fluxes at $2145 \mathrm{~m}$ of water depth in the central Algero-Balearic basin and hypothesized that an important load of material is transported to the deep basin by seasonally controlled deep water formation in the Gulf of Lions.

Lower slope station (SOS1900) recorded higher mass flux values than canyon mouth station (CCC1900). As explained for the middle slope station (SOS1000), the lower canyon loses the constraining effect of the canyon walls and its funneling capacity decreases. Then, the along slope current 


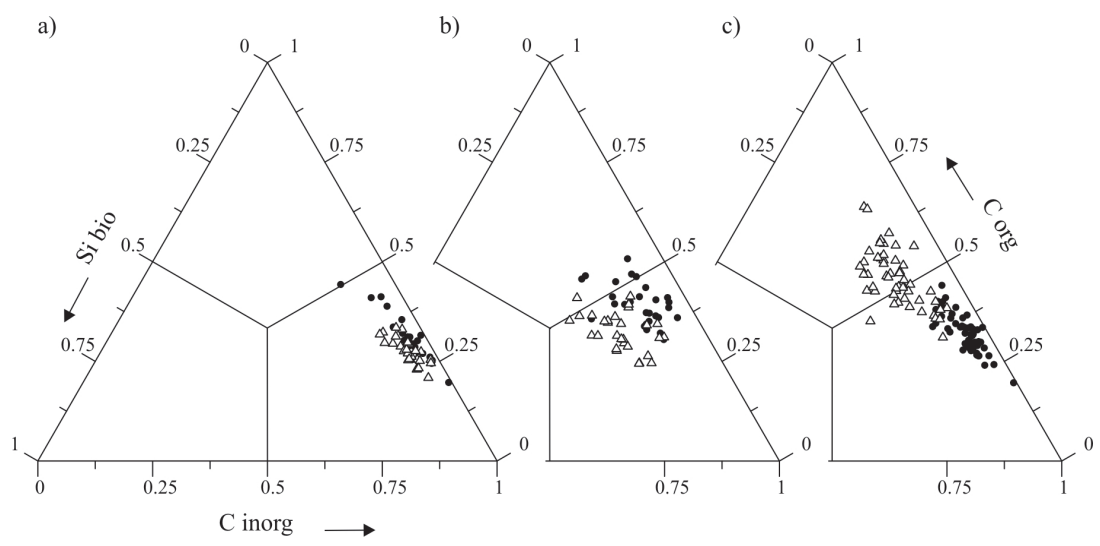

Fig. 8. Correlations of essential biochemical elements organic carbon, inorganic carbon, and biogenic silica, expressed in molar units during (a) the main DSWC event, from January to March 2006, (b) from April to middle July 2006 and (c) the remaining period. Samples from the upper and middle canyon stations are plotted in black dots and samples from the lower canyon, canyon mouth and open slope stations in white up triangles.

circulation spreads the material southwards, causing higher mass fluxes in the open slope than in the canyon stations.

\subsubsection{Post DSWC evolution of particulate fluxes}

After maximum mass fluxes recorded again in late March 2006 (early April 2006 at SOS1900 station), total mass flux at lower canyon, canyon mouth and open slope stations decreased progressively, and did not reach values similar to preDSWC values until late summer 2006 (Fig. 4). This attenuated tendency was probably due to the settling of material from intermediate or bottom nepheloid layers associated with relatively high current velocities (Fig. 3) and the addition of pelagic settling particles (see Sect. 5.2).

Upper and middle canyon stations out of the main DSWC period (i.e., in autumn 2005, spring and summer 2006) presented a continuous flux of material that ranged from $2.6 \mathrm{~g} \mathrm{~m}^{-2} \mathrm{~d}^{-1}$ at CCC1000 station to $8.5 \mathrm{~g} \mathrm{~m}^{-2} \mathrm{~d}^{-1}$ at the LDC300 station (Table 2), and with typical values for the Lacaze-Duthiers upper canyon station of $3.4 \mathrm{~g} \mathrm{~m}^{-2} \mathrm{~d}^{-1}$ similar to the $3.7 \mathrm{~g} \mathrm{~m}^{-2} \mathrm{~d}^{-1}$ value during the long-term measurement at the same station (Heussner et al., 2006). During late summer-autumn 2005 and 2006 months mean total mass fluxes increased and material collected at upper and middle canyon stations was qualitatively similar that settling during the main DSWC period (Fig. 8a, c), reflecting downcanyon transfer of shelf homogenized sediments.

The intensification of material advection to upper and middle canyon stations was recorded concomitantly with the increase of the waves and western river discharge during late summer-autumn months (Fig. 2a, c) as during the 2003/04 period (Palanques et al., 2006). Observations from the HERMES experiment agree with the hypothesis from Bonnin et al. (2008) and Palanques et al. (2008). They suggest that the sedimentation is located mostly at upper canyons during spring and autumn seasons due to the stratification condi- tions that inhibit the downcanyon descend of the water mass and basinwards in winter non-stratified water column. During that period, if storm-induced downwelling couples with DSWC the erosion capability of the water mass increases.

\subsection{Pelagic signal in settled material}

The huge quantity of material caught by the sediment traps during the DSWC event had relatively homogeneous composition (Fig. 6), which suggests that was advected laterally. Besides that, pelagic fluxes may be expected, as sediment trap experiments located at open ocean sites have detected particle fluxes ranging $1-393 \mathrm{mg} \mathrm{m}^{-2} \mathrm{~d}^{-1}$ in the open Algero-Baleric Basin (Zúñiga et al., 2008) and 3$1024 \mathrm{mg} \mathrm{m}^{-2} \mathrm{~d}^{-1}$ in the DYFAMED site (Lee et al., 2009). That suggests a continuous and variable export of material from the euphotic zone. However, in continental slopes, where TMF values are 3 orders of magnitude higher, the pelagic flux would represent a minimum part (Heussner et al., 2006; Martín et al., 2006; Zúñiga et al., 2009). Heussner et al. (2006) reviewed this issue in the GoL area and differentiated between the lateral (resuspended plus rebound) and the pelagic component of the POC flux. They found that advected POC represents, on an annual basis, up to $90 \%$ of the total flux of POC in the Lacaze-Duthiers canyon. However, with this kind of approach, both the intra-annual variability of primary production in the study area (Marty and Chiavérini, 2002) and the impact of extraordinary events such as DSWC (this study) are not reflected.

For example, in late March-April 2006, the widespread increase of chl $a$ offshore (Fig. 2b) indicates the development of a phytoplankton bloom over the study area (Fig. 2a). We could suggest that the increase of the OM and opal contents at the end of March-early April 2006 originates from this increased primary production. However, evidence of pelagic signal in those samples can not be established, mostly 
because during the second flushing of dense shelf waters it is supposed to arrive rebound flux (resuspension of freshly deposited material that has not become incorporated into the sediment, Heussner et al., 2006) from the coastal bloom (Sanchez-Vidal et al., 2009), that may overlap the pelagic flux.

A different scenario takes place during late summer and autumn seasons. High $\mathrm{C}_{\text {org }} / \mathrm{C}_{\text {inorg }}$ ratios were recorded at lower canyon, canyon mouth and open slope stations (Fig. 8c) associated to low total mass fluxes (Fig. 4). Indeed, this total mass fluxes are of the same order that the ones detected in the middle Balearic basin sediment trap experiment, where mean mass fluxes are below the $400 \mathrm{mg} \mathrm{m}^{-2} \mathrm{~d}^{-1}$ (Zúñiga et al., 2007). As current velocities are low (Fig. 3a), little resuspension is expected to occur, and pelagic fluxes may become a significant part of the total mass flux in those deeper stations. At the end of July and in August 2006, TMF peaks with high OM, opal and $\mathrm{CaCO}_{3}$ and minimum siliciclastic contents are detected in LDC1500, CCC1900, SOS1000 and SOS1900 (Figs. 4, 5a, b). During summer water column is stratified with a well developed deep chlorophyll maximum (Estrada et al., 1993). In those conditions primary productivity has been related to the development of diazotrophic communities (Marty et al., 2002, 2009) that may induce vertical transfer events (Migon et al., 2002) that could explain the increase in TMF. Indeed, the organic matter settled in August has low $\delta^{15} \mathrm{~N}$ values associated to N2fixation (Sanchez-Vidal et al., 2009). In the autumn season, a weak peak of TMF is detected in CCC1500, LDC1500, CCC1900 (November 2005) and in the open slope stations (both November 2005 and September 2006) (Fig. 4). The material is characterized by high OM and opal contents (Fig. 5), indicating the settling of organic rich particles (up to $15 \%$ of OM in early September in CCC1900). Increase in significant wave heights suggest that storms where affecting that region (Fig. 2c), mixing the water column. The increase in organic rich mass fluxes detected in the sediment traps could be linked to the rapid transference of particles downwards that has been observed during non-stratified water column conditions (Migon et al., 2002; Zúñiga et al., 2007).

\section{Conclusions}

Several conclusions may be drawn from this sediment trap experiment that has recorded settling particle fluxes from upper canyons and slope regions to the deep basin in the Western Mediterranean Sea. An intense DSWC event took place and was registered by all sediment traps. Near-bottom particles fluxes reflected a quick response of the system as a consequence of the major physical forcing (i.e. dense shelf water cascading). This mechanism induced qualitative and quantitative changes in material settled highlighting the different behavior between stations. Upper and middle canyon was primarily affected by continuous cross-slope exchanges with the shelf. The deeper ones (canyon mouth and slope) were less affected by that horizontal transferences and shelf material arrived associated to the DSWC event.

The severe DSWC event observed during January-March 2006 imposed a change in the sedimentation. Upper canyons acted as seasonal depocenters of particulate matter of shelf origin during end-summer and autumn and as bypass zones during the DSWC event. The strong downcanyon currents during the DSWC event eroded and transported material quickly basinwards inducing significant particle fluxes increase. At the lower canyon, canyon mouth and open slope stations the effect of the DSWC on the flux and composition of particles lasted for 6 months.

The upper southern open slope was also directly impacted by DSWC as the dense waters escaped the lower canyons to flow along the isobaths. This denotes the capacity such events to erode shelf material, funnel through canyons and spread it southwardly. Therefore DSWC may become an important factor for the sedimentation in the middle and lower slope of the northwestern Mediterranean.

The pelagic component of the total mass flux represented a minimum part of the total mass due to the large quantity of material transported by cascading waters. However, during calmed conditions total mass fluxes in lower canyon, canyon mouth and open slope stations were of the same order of magnitude than those detected in the middle of the Balearic basin, suggesting that pelagic fluxes may become a significant part of the total mass flux.

Acknowledgements. We thank all participants (G. Saragoni, J. Avril, J. Martín, J. Guillén and J. A. Salvador) and crews of R/V Garcia del Cid and R/V Universitatis for their help and dedication, and M. Guart, A. Alonso and E. Pelfort for their help in laboratory works. We also thank anonymous referees for their useful comments which improved the manuscript. This research has been supported by HERMES (GOCE-CT-2005-511234-1), SESAME (GOCE-036949), HERMIONE (FP7-ENV-2008-1-226354), and GRACCIE (CSD2007-00067, Consolider-Ingenio Program) research projects, a Generalitat de Catalunya "Grups de Recerca Consolidats" grant (2009 SGR-1305) and a FP7 Marie Curie Reintegration Grant (PERG04-GA-2008-239175). C. Pasqual is supported by an F.P.U. grant from the Spanish government.

Edited by: M. Dai

\section{References}

Antia, A. N.: Solubilization of particles in sediment traps: revising the stoichiometry of mixed layer export, Biogeosciences, 2, 189204, 2005,

http://www.biogeosciences.net/2/189/2005/.

Bethoux, J. P. and Gentili, B.: Functioning of the Mediterranean Sea: past and present changes related to freshwater input and climate changes, J. Marine Syst., 20, 33-47, doi:10.1016/S09247963(98)00069-4, 1999.

Bethoux, J. P., Durieu de Madron, X., Nyffeler, F., and Tailliez, D.: Deep water in the western Mediterranean: peculiar 1999 and 
2000 characteristics, shelf formation hypothesis, variability since 1970 and geochemical inferences, J. Marine Syst., 33-34, 117131, doi:10.1016/S0924-7963(02)00055-6, 2002.

Bonnin, J., Heussner, S., Calafat, A., Fabres, J., Palanques, A., Durrieu de Madron, X., Canals, M., Puig, P., Avril, J., and Delsaut, N.: Comparison of horizontal and downward particle fluxes across canyons of the Gulf of Lions (NW Mediterranean): Meteorological and hydrodynamical forcing, Cont. Shelf Res., 28(15), 1957-1970, doi:10.1016/j.csr.2008.06.004, 2008.

Bourrin, F. and Durrieu de Madron, X.: Contribution of the study of coastal rivers and associated prodeltas to sediment supply in North-western Mediterranean Sea (Gulf of Lions), Vie Milieu, 56(4), 307-314, 2006.

Bourrin, F., Durrieu de Madron, X., Heussner, S., and Estournel, C.: Impact of winter dense water formation on shelf sediment erosion (evidence from the Gulf of Lions, NW Mediterranean), Cont. Shelf Res., 28, 1984-1999, doi:10.1016/j.csr.2008.06.006, 2008.

Bosc, E., Bricaud, A., and Antoine, D.: Seasonal and interannual variability in algal biomass and primary production in the Mediterranean Sea, as derived from four years of SeaWiFS observations, Global Biogeochem. Cy., 18, GB1005, doi:10.1029/2003GB002034, 2004.

Buesseler, K. O., Antia, Avan, N., Chen, M., Fowler, S. W., Gardner, W. D., Gustafsson, O., Harada, K., Michaels, A. F., Rutgers van der Loeff, M., Sarin, M., Steinberg, D., and Trull, T.: An assessment of the use of sediment traps for estimating upper ocean particle fluxes, J. Mar. Res., 65, 345-416, 2007.

Butman, C. A.: Sediment trap biases in turbulent flows: Results from a laboratory flume study, J. Mar. Res., 44, 645-693, 1986.

Canals, M., Puig, P., Durrieu de Madron, X., Heussner, S., Palanques, A., and Fabres, J.: Flushing submarine canyons, Nature, 444, 354-357, doi:10.1038/nature0527, 2006.

Canals, M., Danovaro, R., Heussner, S., Lykousis, V., Puig, P., Trincadi, F., Calafat, A. M., Durrieu de Madron, X., Palanques, A., and Sanchez-Vidal, A.: Cascades in Mediterranean Submarine Grand Canyons, Oceanography, 22(1), 26-43, 2009.

Carbonne, J.: Développement de techniques de prélèvement et d'analyse de la matière particulaire en océanologie. Diplôme universitaire de recherche, Université de Perpignan- 72 pp., 1991.

Courp, T. and Monaco, A.: Sediment dispersal and accumulation on the continental margin of the Gulf of Lions: sedimentary budget, Cont. Shelf Res., 10, 1063-1087, doi:10.1016/02784343(90)90075-W, 1990.

DeGeest, A. L., Mullenbach, B. L., Puig, P., Nittrouer, C. A., Drexler, T. M., Durrieu de Madron, X., and Orange, D. L.: Sediment accumulation in the western Gulf of Lions, France: The role of Cap de Creus Canyon in linking shelf and slope sediment dispersal systems, Cont. Shelf Res., 28(15), 2031-2047, doi:10.1016/j.csr.2008.02.008, 2008.

Durrieu de Madron, X. and Panouse, M.: Transport de matière en suspension sur le plateau continental du Golfe du Lion - Situation estivale et hivernale. CR ACAD SCI II A, 322, 1061-1070, 1996.

Durrieu de Madron, X., Zervakis, V., Theocharis, A., and Georgopoulos, D.: Comments to "Cascades of dense water around the world ocean", Progr. Oceanogr., 64, 83-90, doi:10.1016/j.pocean.2004.08.004, 2005.

Estrada, M., Marrasé, C., Latasa, M., Berdalet, E., Delgado, M., and Riera, T.: Variability of deep chlorophyll maximum characteristics in the Northwestern Mediterranean, Mar. Ecol-Prog. Ser., 92, 289-300, 1993.

Fabres, J., Calafat, A., Sanchez-Vidal, A., Canals, M., and Heussner, S.: Composition and spatio-temporal variability of particle fluxes in the Western Alboran Gyre, Mediterranean Sea., J. Marine Syst., 33-34, 431-456, doi:10.1016/S0924-7963(02)000702, 2002.

Fabres, J., Tesi, T., Velez, J., Batista, Z., Lee, C., Calafat, A., Heussner, S., Palanques, A., and Miserocchi, S.: Seasonal and eventcontrolled export of organic matter from the shelf towards the Gulf of Lions continental slope, Cont. Shelf Res., 28(15), 19711983, doi:10.1016/j.csr.2008.04.010, 2008.

Flexas, M. M., Durrieu de Madron, X., Garcia, M. A., Canals, M., and Arnau, P.: Flow variability in the Gulf of Lions during the MATER HFF experiment (March-May 1997), J. Marine Syst., 33-34, 197-214, doi:10.1016/S0924-7963(02)00059-3, 2002.

Font, J., Puig, P., Salat, J., Palanques, A., and Emilianov, M.: Sequence of hydrographic changes in NW Mediterranean deep water due to the exceptional winter of 2005, Sci. Mar., 71, 339-346, 2007.

Fuda, J. L., Millot, C., Taupier-Letage, I., Send, U., and Bocognano, J. M.: XBT monitoring of a meridian section across the western Mediterranean Sea, Deep-Sea Res. Pt. I, 47, 2191-2218, doi:10.1016/S0967-0637(00)00018-2, 2000.

Gardner, W. D.: Sediment trap dynamics and calibration: a laboratory evaluation, J. Mar. Res., 38, 17-39, 1980.

Gardner, W. D., Biscaye, P. E., and Richardson, M. J.: A sediment trap experiment in the Vema Channel to evaluate the effect of horizontal particle fluxes on measured vertical fluxes, J. Mar. Res., 58, 995-1028, 1997.

Heussner, S., Ratti, C., and Carbonne, J.: The PPS 3 time-series sediment trap and the trap sample processing techniques used during the ECOMARGE experiment, Cont. Shelf Res., 10, 943958, doi:10.1016/0278-4343(90)90069-X, 1990.

Heussner, S., Durrieu de Madron, X., Radakovitch, O., Beaufort, L., E. Biscaye, P., Carbonne, J., Delsaut, N., Etcheber, H., and Monaco, A.: Spatial and temporal patterns of downward particle fluxes on the continental slope of the Bay of Biscay (northeastern Atlantic), Deep-Sea Res. Pt. II, 46(10), 2101-2146, doi:10.1016/S0967-0645(99)00057-0, 1999.

Heussner, S., Durrieu de Madron, X., Calafat, A., Canals, M., Carbonne, J., Delsaut, N., and Saragoni, G.: Spatial and temporal variability of downward particle fluxes on a continental slope: Lessons from an 8-yr experiment in the Gulf of Lions (NW Mediterranean), Mar. Geol., 234, 63-92, doi:10.1016/j.margeo.2006.09.003, 2006.

Ivanov, V. V., Shapiro, G. I., Huthnance, J. M., Aleynik, D. L., and Golovin, P. N.: Cascades of dense water around the world ocean, Prog. Oceanogr., 60, 47-98, doi:10.1016/j.pocean.2003.12.002, 2004.

Kerhervé, P., Minagawa, M., Heussner, S., and Monaco, A.: Stable isotopes $\left({ }^{13} \mathrm{C} /{ }^{12} \mathrm{C}\right.$ and $\left.{ }^{15} \mathrm{~N} /{ }^{14} \mathrm{~N}\right)$ in settling organic matter of the northwestern Mediterranean Sea: biogeochemical implications, Oceanol. Acta, 24, 77-85, doi:10.1016/S0399-1784(00)011117, 2001.

Lee, C., Hedges, J. I., Wakeham, S. G., and Zhu, N.: Effectiveness of various treatments in retarding microbial activity in sediment trap material and their effects on the collection of swimmers, 
Limnol. Oceanogr., 37(1), 117-130, 1992.

Lee, C., Wakeham, S. G., Peterson, M. L., Cochran, J. K., Miquel, J. C., Armstrong, R. A., Fowler, S. W., Hirschberg, D., Beck, A., and Xue, J.: Particulate matter fluxes in timeseries and settling velocity sediment traps in the northwestern Mediterranean Sea. Deep-Sea Res. Pt. II, 56(18), 1420-1436, doi:10.1016/j.dsr2.2008.11.029, 2009.

Lefevre, D., Minas, H. J., Minas, M., Robinson, C., Le B. Williams, P. J., and Woodward, E. M. S.: Review of gross community production, primary production, net community production and dark community respiration in the Gulf of Lions, Deep-Sea Res. Pt. II, 44, 801-819, doi:10.1016/S0967-0645(96)00091-4, 1997.

Lopez-Jurado, J. L., Gonzalez-Pola, C., and Velez-Belchi, P.: Observation of an abrupt disruption of the long-term warming trend at the Balearic Sea, western Mediterranean Sea, in summer 2005, Geophys. Res. Lett., 32, L24606, doi:10.1029/2005GL024430, 2005.

Martín, J., Palanques, A., and Puig, P.: Composition and variability of downward particulate matter fluxes in the Palamós submarine canyon (NW Mediterranean), J. Mar. Syst., 60, 75-97, doi:10.1016/j.jmarsys.2005.09.010, 2006.

Marty, J. C., Chiaverini, J., Pizay, M. D., and Avril, B.: Seasonal and interannual dynamics of nutrients and phytoplankton pigments in the western Mediterranean Sea at the DYFAMED time series station (1991-1999), Deep-Sea Res. Pt. II, 49, 1965-1985, 2002.

Marty, J. C., Garcia, N., and Raimbault, P.: Phytoplankton dynamics and primary production under late summer conditions in the NW Mediterranean Sea, Deep-Sea Res. Pt. I, 55(9), 1131-1149, doi:10.1016/j.dsr.2008.05.001, 2008.

Marty, J. C., Goutx, M., Guigue, C., Leblond, N., and Raimbault, P.: Short-term changes in particulate fluxes measured by drifting sediment traps during end summer oligotrophic regime in the NW Mediterranean Sea, Biogeosciences, 6, 887-899, 2009, http://www.biogeosciences.net/6/887/2009/.

Migon, C., Sandroni, V., Marty, J., Gasser, B., and Miquel, J.: Transfer of atmospheric matter through the euphotic layer in the northwestern Mediterranean: seasonal pattern and driving forces, Deep-Sea Res. Pt. II, 49, 2125-2141, doi:10.1016/S09670645(02)00031-0, 2002.

Millot, C.: Circulation in the Western Mediterranean Sea, J. Marine Syst., 20, 423-442, doi:10.1016/S0924-7963(98)00078-5, 1999.

Monaco, A., Courp, T., Heussner, S., Carbonne, J., Fowler, S. W., and Deniaux, B.: Seasonality and composition of particulate fluxes during ECOMARGE-I, western Gulf of Lions, Cont. Shelf Res., 10, 959-987, doi:10.1016/0278-4343(90)90070-3, 1990.

Mortlock, R. A. and Froelich, P. N.: A simple method for the rapid determination of biogenic opal in pelagic marine sediments, Deep-Sea Res., 36, 1415-1426, doi:10.1016/01980149(89)90092-7, 1989.

Ogston, A. S., Drexler, T. M., and Puig, P.: Sediment delivery, resuspension, and transport in two contrasting canyon environments in the southwest Gulf of Lions, Cont. Shelf Res., 28(15), 2000-2016, doi:10.1016/j.csr.2008.02.012, 2008.

Palanques, A., Durrieu de Madron, X., Puig, P., Fabres, J., Guillén, J., Calafat, A., Canals, M., Heussner, S., and Bonnin, J.: Suspended sediment fluxes and transport processes in the Gulf of Lions submarine canyons. The role of storms and dense water cascading, Mar. Geol., 234, 43-61, doi:10.1016/j.margeo.2006.09.002, 2006.

Palanques, A., Guillén, J., Puig, P., and Durrieu de Madron, X.: Storm-driven shelf-to-canyon suspended sediment transport at the southwestern Gulf of Lions, Cont. Shelf Res., 28(15), 19471956, doi:10.1016/j.csr.2008.03.020, 2008.

Palanques, A., Puig, P., Latasa, M., and Scharek, R.: Deep sediment transport induced by storms and dense shelf-water cascading in the northwestern Mediterranean basin, Deep-Sea Res., 56, 425434, doi:10.1016/j.dsr.2008.11.002, 2009.

Puig, P., Palanques, A., Orange, D. L., Lastras, G., and Canals, M.: Dense shelf water cascades and sedimentary furrow formation in the Cap de Creus Canyon, northwestern Mediterranean Sea, Cont. Shelf Res., 28(15), 2017-2030, doi:10.1016/j.csr.2008.05.002, 2008.

Roussiez, V., Ludwig, W., Monaco, A., Probst, J. L., Bouloubassi, I., Buscail, R., and Saragoni, G.: Sources and sinks of sedimentbound contaminants in the Gulf of Lions (NW Mediterranean Sea): A multi-tracer approach, Cont. Shelf Res., 26(16), 18431857, doi:10.1016/j.csr.2006.04.010, 2006.

Sanchez-Vidal, A., Pasqual, C., Kerhervé, P., Palanques, A., Calafat, A., Heussner, S., Durrieu de Madron, X., Canals, M., and Puig, P.: Impact of dense shelf water cascading on the transfer of organic matter to deep western Mediterranean basin, Geophys. Res. Lett. 35, L05605, doi:10.1029/2007GL032825, 2008.

Sanchez-Vidal, A., Pasqual, C., Kerhervé, P., Heussner, S., Calafat, A., Palanques, A., Durrieu de Madron, X., Canals, M., and Puig, P.: Across margin export of organic matter by cascading events traced by stable isotopes northwestern Mediterranean Sea, Limnol. Oceanogr., 54 (5), 1488-1500, 2009.

Serrat, P., Ludwig, W., Navarro, B., and Blazi, J. L.: Variabilité spatio-temporelle des flux de matières en suspension d'un fleuve côtier méditerranéen: la Têt (France). Spatial and temporal variability of sediment fluxes from a coastal Mediterranean river: the Têt (France), Cr. Acad. Sci. IIA, 333(7), 389-397, doi:10.1016/S1251-8050(01)01652-4, 2001.

Ulses, C., Estournel, C., Durrieu de Madron, X., and Palanques, A.: Suspended sediment transport in the Gulf of Lions (NW Mediterranean): Impact of extreme storms and floods, Cont. Shelf Res., 28(15), 2048-2070, doi:10.1016/j.csr.2008.01.015, 2008a.

Ulses, C., Estournel, C., Puig, P., Durrieu de Madron, X., and Marsaleix, P.: Dense shelf water cascading in the northwestern Mediterranean during the cold winter 2005: Quantification of the export through the Gulf of Lion and the Catalan margin, Geophys. Res. Lett., 35, L07610, doi:10.1029/2008GL033257, 2008 b.

Vidussi, F., Marty, J., and Chiavérini, J.: Phytoplankton pigment variations during the transition from spring bloom to oligotrophy in the northwestern Mediterranean sea, Deep-Sea Res. Pt. I, 47, 423-445, doi:10.1016/S0967-0637(99)00097-7, 2000.

Van Wambeke, F., Heussner, S., Diaz, F., Raimbault, P., and Conan, P.: Small-scale variability in the coupling/uncoupling of bacteria, phytoplankton and organic carbon fluxes along the continental margin of the Gulf of Lions, Northwestern Mediterranean Sea, J. Marine Syst., 33-34, 411-429, doi:10.1016/S09247963(02)00069-6, 2002.

Zúñiga, D., Calafat, A., Sanchez-Vidal, A., Canals, M., Price, B., Heussner, S., and Miserocchi, S.: Particulate organic carbon budget in the open Algero-Balearic Basin (Western Mediterranean): Assessment from a one-year sediment trap experiment, Deep Sea 
Res. Pt. I, 54(9), 1530-1548, doi:10.1016/j.dsr2.2008.11.029, 2007.

Zúñiga, D., Calafat, A., Heussner, S., Miserocchi, S., SanchezVidal, A., Garcia-Orellana, J., Canals, M., Sánchez-Cabeza, J. A., Carbonne, J., Delsaut, N., and Saragoni, G.: Composition and temporal evolution of particle fluxes in the open Algero-Balearic basin (Western Mediterranean), J. Marine Syst., 70, 196-214, doi:10.1016/j.jmarsys.2007.05.007, 2008.
Zúñiga, D, Flexas, M. M., Sanchez-Vidal, A., Coenjaerts, J., Calafat, J., Jordà, G., García-Orellana, J., Puigdefàbregas, J., Canals, M., Espino, M., Sardàg, F., and Company, J. B.: Particle fluxes dynamics in blanes submarine canyon (Northwestern Mediterranean), Prog. Oceanogr., 82(4), 239-251, doi:10.1016/j.pocean.2009.07.002, 2009. 